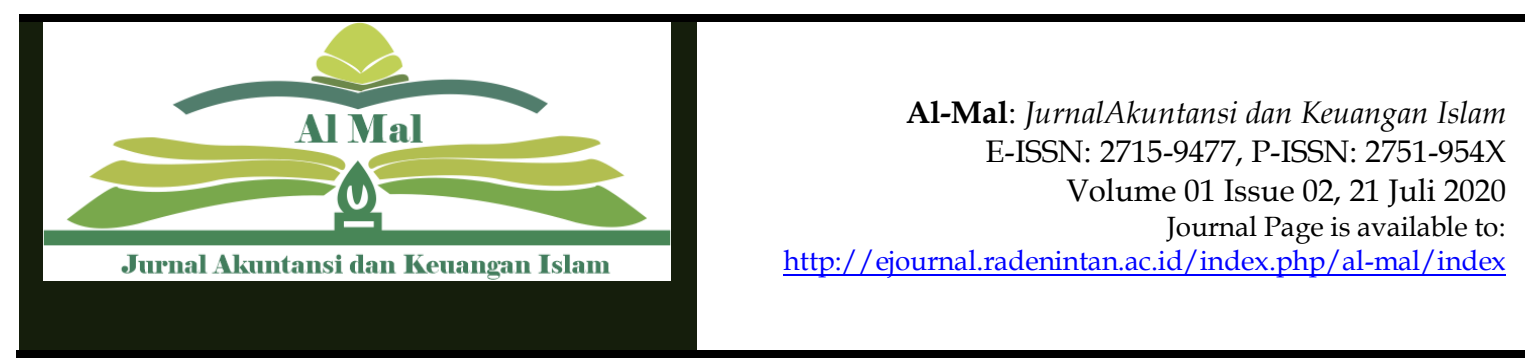

\title{
Pengaruh Risiko Bisnis, Financial Distress, Dan Kinerja Perusahaan Terhadap Remunerasi Direksi
}

\author{
Muhammad Yusuf ${ }^{1}$,Ane Tri Septiani2 ${ }^{*}$
}

$1,2^{*}$ Departement of Economics, Faculty of Economics and Business, Universitas Negeri Jakarta, Indonesia

\begin{tabular}{l}
\hline \multicolumn{1}{c}{ ARTICLE INFO } \\
\hline Article history: \\
Received 06-13-2020 \\
Revised 07-07-2020 \\
Accepted 09-07-2020 \\
Available 21-07-2020 \\
Revised (1) 17-07-2022 \\
Revised (1) 18-07-2022 \\
Accepted 19-07-2022 \\
Revised Available 19-07-2022 \\
Kata Kunci: \\
Risiko Usaha, Kesulitan Keuangan, \\
Kinerja Perusahaan, Remunerasi \\
Direksi \\
\hline
\end{tabular}

Paper type: Research paper

Please cite this article: Yusuf, M, Septiani, A. "Pengaruh resiko bisnis, financial distress dan kinerja perusahaan terhadap remunerasi direksi" Al-Mal: Jurnal Akuntansi dan Keuangan Islam [ONLINE], Volume 01 Number 02 (Juli 21, 2020)

Cite this document:

Al-Mal 2th edition

*Corresponding author

e-mail: aneseptiani51@gmail.com

Page: $229-245$

\begin{abstract}
ABSTRAK
Penelitian ini bertujuan untuk menguji pengaruh hubungan antara risiko bisnis, financial distress, dan kinerja perusahaan terhadap remunerasi direksi. Sumber data yang digunakan yaitu data sekunder, dengan populasi perusahaan sektor perbankan yang terdaftar di BEI tahun 2011-2016. Metode penentuan sampel menggunakan purposive sampling sehingga sampel yang didapatkan peneliti sebanyak 25 perusahaan. Penelitian ini menggunakan metode pendekatan kuantitatif dan untuk menguji hipotesis dengan bantuan SPSS. Hasil penelitian menunjukkan bahwa resiko bisnis dan financial distress tidak mempunyai pengaruh yang positif terhadap remunerasi direksi, sedangkan kinerja perusahaan mempunyai pengaruh yang positif dan signifikan terhadap remunerasi direksi. Keterbatasan penelitian ini yaitu hanya membahas seberapa besar pengaruh resiko bisnis, financial distress dan kinerja perusahaan terhadap remunerasi direksi, sehingga membuka peluang untuk peneliti-peneliti yang baru dengan mengangkat tema yang sama dengan jumlah sampel objek penelitian yang lebih banyak atau menambahkan variabel-variabel yang lain yang akan mempengaruhi variabel remunerasi direksi. Implikasi dari penelitian ini adalah kebijakan pemberian remunerasi oleh perusahaan dipengaruhi oleh kinerja perusahaan, sedangkan resiko bisni dan financial distress tidak dapat memberikan informasi tentang seberapa besar pengaruh terhadap remunerasi direksi, hal ini tentu berkaitan bagaimana kondisi kinerja perusahaan saat itu serta risiko kredit khususnya pada perusahaan perbankan pada saat itu.
\end{abstract}




\begin{abstract}
This study aims to examine the effect of the relationship between business risk, financial distress, and company performance on the remuneration of directors. The data source used is secondary data, with a population of banking sector companies listed on the Indonesia Stock Exchange in 2011-2016. The method of determining the sample using purposive sampling so that the sample obtained by researchers as many as 25 companies. This study uses a quantitative approach and to test the hypothesis with the help of SPSS. The results showed that business risk and financial distress did not have a positive effect on the remuneration of the directors, while the company's performance had a positive and significant effect on the remuneration of the directors. The limitation of this study is that it only discusses how much influence business risk, financial distress and company performance have on the remuneration of directors, thus opening up opportunities for new researchers with the same theme with a larger number of samples of research objects or adding other variables. which will affect the variable of remuneration of directors. The implication of this research is that the company's remuneration policy is influenced by the company's performance, while business risk and financial distress cannot provide information about how much influence it has on the remuneration of directors, this is certainly related to the current condition of the company's performance and credit risk, especially in banking companies. at the time.
\end{abstract}

\title{
Keyword: Business Risk, Financial Distress, Company Performance, Remuneration Of Directors
}

\section{PENDAHULUAN}

Krisis ekonomi global yang terjadi pada tahun 2008 terjadi dikarenakan adanya dorongan untuk konsumsi (propincity to consume). Berawal dari rakyat Amerika Serikat yang hidup dalam konsumerisme di luar batas yang membuat mereka hidup dalam hutang. Tingginya jumlah permintaan pinjaman subprime mortage menyebabkan lembaga keuangan yang memberikan kredit mulai kehilangan likuiditasnya. Langkah yang ditempuh untuk mengatasi likuiditas yang buruk yaitu dengan sekuritisasi subprime mortage menjadi mortagebacked securities (MBS) yang bertujuan untuk memperoleh suntikan dana segar dan mengalihkan risiko gagal bayar kepada investor baru. Tidak selesai sampai pada MBS, melalui rekayasa keuangan yang kompleks MBS diresekuritisasi lagi menjadi sekuritas lainnya. Tingginya permintaan pinjaman memicu perubahan kebijakan moneter AS berupa peningkatan suku bunga 
yang selanjutnya membuat para debitur subprime mortage mengalami gagal bayar. Gagal bayar menyeret semua investor maupun lembaga yang terlibat dalam penjaminan likuiditas subprime mortage. Krisis tersebut merambat ke sektor rill dan non-keuangan. (Detk.com, 2017).

Kesalahan pengambilan keputusan dapat berdampak pada bangkrutnya suatu perusahaan. Lehman Brothers merupakan salah satu perusahaan Wall Street yang mengalami kebangkrutan karena telah ikut serta mendanai subprime mortage. Hal tersebut membuat masyarakat luas berpikir tentang cara mengatasi potensi risiko bisnis dan penurunan kinerja perusahaan yang akan terjadi di masa depan. Remunerasi menjadi perhatian banyak negara setelah terjadinya krisis keuangan global yang mengakibatkan kondisi perekonomian di banyak negara terpuruk (Wells, 2015).

Perbedaan kepentingan dan asimetri informasi yang terjadi antara agent dan principal berpotensi menyebabkan kerugian yang material bagi perusahaan. Diperlukan adanya suatu langkah yang ditempuh perusahaan untuk tetap menjaga kinerja dan kondisi keuangan perusahaan. Remunerasi sebagai bagian dari mekanisme tata kelola perusahaan dianggap mampu mengatasi menurunnya kinerja. Remunerasi yang diberikan kepada pihak manajemen eksekutif dianggap dapat memotivasi untuk meningkatan kinerja dan komptensi dalam pengelolaan perusahaan (Robert N Anthony, 2007) Remunerasi merupakan imbalan atau balas jasa terhadap kinerja karyawan yang diwujudkan dalam bentuk finansial dan non-finansial. Imbalan tersebut dapat berupa gaji, bonus, opsi saham, restricted share, dana pensiun, dan manfaat lainnya (Neokleous, 2015). Di Indonesia hal ini merupakan topik yang menarik untuk dibahas, terutama pada sektor perbankan. Peraturan Bank Indonesia No.8/4/ PBI/ 2006 tentang pelaksanaan Good Corporate Governance (GCG) bank umum mewajibkan pengungkapan remunerasi dan segala fasilitas yang diberikan pada laporan Good Corprate Governance. Semua perusahaan yang terdaftar di Bursa Efek Indonesia (BEI) wajib untuk melakukan pengungkapan remunerasi khususnya yang diberikan kepada direksi dan 
komisaris. Perusahaan sektor perbankan yang bergerak dalam bidang jasa pemberian kredit memiliki risiko bisnis yang cukup besar. Pihak direksi diharapkan dapat memperbaiki kredit yang buruk dengan membuat suatu keputusan. (Heaney, 2005).

mempelajari studi tentang risiko dan remunerasi, yang menyatakan bahwa pihak principal akan mengeluarkan biaya berupa remunerasi kepada pengambil keputusan sebagai upah dalam mengambil risiko. Sebaliknya (Ruparelia, 2016) yang menyatakan bahwa pemberian remunerasi yang lebih besar akan diberikan kepada perusahaan yang sehat.

Perusahaan yang sedang mengalami financial distress cenderung tidak akan melakukan pengeluaran kas terhadap biaya-biaya selain keperluan operasional. (Abdullah, 2006) menyebutkan bahwa perusahaan dalam keadaan financial distress akan membayar total remunerasi lebih rendah dibandingkan perusahaan dalam keadaan sehat hal tersebut sesuai dengan penelitian (Probohudono et al., 2016) yang menyatakan ketika perusahaan dalam keadaan financial distress, kondisi keuangan dalam perusahaan sedang mengalami penurunan serta perusahaan akan mengalami kesulitan dalam melakukan pembayaran utang. Sebaliknya, ketika keadaan perusahaan dalam kondisi nonfinancial distress, maka kondisi keuangan yang ada dalam perusahaan sedang dalam keadaan normal akan berdampak pada besarnya pemberian remunerasi direksi. Hal tersebut bertentangan (Bebchuk \& Fried, 2006) yang menyatakan bahwa ketika perusahaan sedang mengalami non-financial distress harus tetap menjaga pembayaran yang berlebih kepada direksi. PT Modern Internasional Tbk (Sevel) yang memiliki gerai 190 unit pada tahun 2014 yang kemudian perlahan menurun pada tahun 2016 menjadi 175 unit. Hal ini disebabkan karena pada tahun 2016 Sevel mengalami kesulitan keuangan dan memperoleh laba negatif sebesar 162 miliar, hal ini berdampak pada penurunan pembayaran yang dilakukan untuk pihak eksternal dan internal perusahaan (www.kompas.com, 2017). 
Peningkatan kinerja yang baik akan berpengaruh terhadap besaran remunerasi yang akan diterima oleh direksi dan hal tersebut membuat kinerja perusahaan menjadi baik (Ruparelia, 2016) Peningkatan kinerja perusahaan ditentukan oleh agent. Agent dalam hal ini adalah dewan direksi dan dewan komisaris sebagai pimpinan tertinggi perusahaan. Peningkatan kinerja yang baik dan memiliki potensi memperoleh laba perusahaan yang lebih besar pada masa mendatang akan berpotensi terhadap peningkatan jumlah remunerasi yang diberikan.

Penelitian yang membahas tentang remunerasi direksi dalam sektor perbankan masih sangat minim dilakukan di Indonesia. Sektor perbankan dipilih dikarenakan dalam pelaksanaan Good Corporate Governance mengharuskan bank untuk mengungkapkan jumlah remunerasi yang diberikan kepada direksi khususnya yang menggunakan variabel risiko bisnis.

Penelitian ini diharapkan dapat menambah wawasan penulis dan pembaca terhadap faktor-faktor yang mempengaruhi remunerasi direksi. Bagi pihak principal dan stakeholders, penelitian ini dapat memberikan pandangan pengaruh financial distress, risiko bisnis, dan kinerja perusahaan terhadap remunerasi direksi. Bagi pemerintah, sebagai bahan evaluasi dalam pertimbangan suatu regulasi remunerasi yang sesuai untuk para direksi dan dewan komisaris.

\section{METODOLOGI PENELITIAN}

Jenis penelitian yang digunakan dalam penelitian ini adalah penelitian deskriptif dengan pendekatan kuantitatif dengan jenis data sekunder. Dalam hal ini metode kuantitatif menggunakan data kombinasi time series dan cross section atau pooled data. Menurut (Yusuf M. a., 2019) penggunaan data panel dalam sebuah observasi mempunyai beberapa keuntungan yang diperoleh.

Objek dari penelitian "Pengaruh Risiko Bisnis, Financial Distress, dan Return on Assets Terhadap Remunerasi Direksi" ini adalah laporan perusahaan sektor perbankan yang terdaftar pada Bursa Efek Indonesia selama periode 
2011-2016 dan laporan keuangan tersebut dipublikasikan pada situs resmi perusahaan dan situs resmi Bursa Efek Indonesia (www.idx.co.id, 2020) selama periode 2011-2016. Penarikan sampel dalam penelitian ini menggunakan metode purposive sampling. Menurut (Sugiyono, 2018) purposive sampling adalah teknik penentuan sampel dengan pertimbangan tertentu.

Kriteria yang digunakan untuk memilih sampel adalah sebagai berikut:

1. Perusahaan sektor perbankan yang terdaftar di Bursa Efek Indonesia selama periode 2011-2016.

1. Perusahaan mengeluarkan dan mempublikasikan laporan keuangan selama periode 2011-2016.

2. Data-data yang berkaitan dengan variabel penelitian tersedia lengkap pada publikasi perusahaan selama periode 2011-2016.

Hingga tahun 2016, terdapat 43 perusahaan sektor perbankan yang telah mendaftarkan sahamnya pada Bursa Efek Indonesia. Jumlah ini meningkat dari tahun 2011 yaitu berjumlah 30 perusahaan.

\section{HASIL DAN PEMBAHASAN}

Hasil perhitungan koefisien determinasi penelitian ini dapat terlihat pada Tabel berikut:

\section{Tabel 4.1}

Hasil Uji $\mathbf{R}^{2}$ dan Adjusted $\mathbf{R}^{2}$

\begin{tabular}{|l|l|l|l|l|}
\hline Model & R & R Square & $\begin{array}{c}\text { Adjusted R } \\
\text { Square }\end{array}$ & $\begin{array}{c}\text { Std. Error of the } \\
\text { Estimate }\end{array}$ \\
\hline 1 & $.715^{\mathrm{a}}$ & .511 & .499 & .78983 \\
\hline
\end{tabular}

a. Predictors: (Constant), ROA, FDSTR, NPL

b. Dependent Variable: LN.RD

Sumber: Data diolah dengan SPSS 23, 2018.

Berdasarkan Tabel 4.1 hasil pengujian regresi berganda didapat nilai adjusted R2 adalah 0,499 atau 49,9\%. Artinya seluruh variabel independen yang terdiri dari non performing loan, financial distress dan return on assets mampu menjelaskan variasi dari variabel dependen yaitu remunerasi direksi sebesar $49,9 \%$, sedangkan sisanya yaitu sebesar 50,1\% dapat dijelaskan oleh faktor- 
faktor lain seperti ukuran perusahaan, struktur kepemilikan dan komposisi dewan direksi perusahaan (Probohudono et al., 2016) yang tidak diikutsertakan dalam model penelitian. Adjusted R2 49,9\% merupakan pengaruh dari variabel risiko bisnis, financial distress dan kinerja perusahaan.

Hasil perhitungan uji $t$ ini dapat dilihat pada Tabel 4.2 berikut ini:

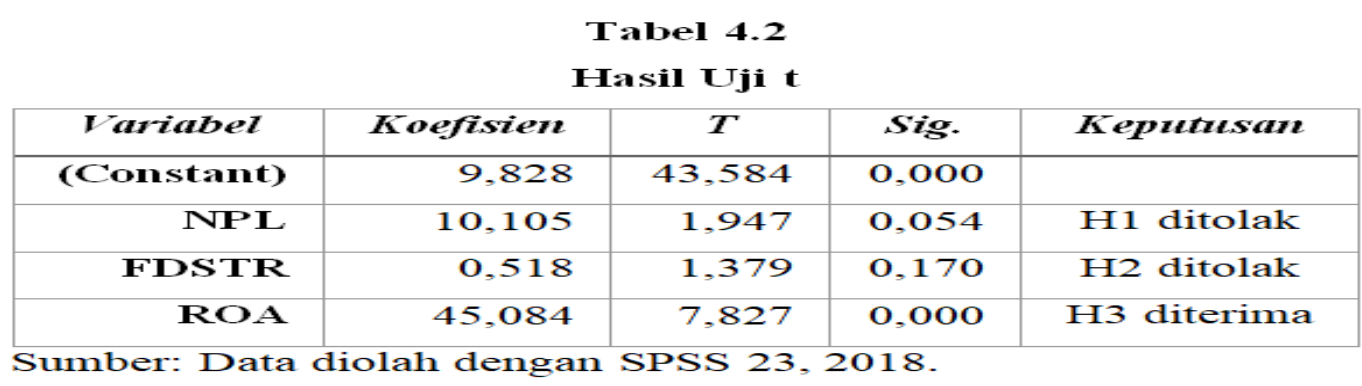

Adapun persamaan yang terbentuk dari pengujian regresi di atas adalah sebagai berikut:

$$
\text { LN.RD }=9,828+0,518 \text { FDSTR }+45,084 \mathrm{ROA}+10,105 \mathrm{NPL}
$$

Berdasarkan hasil analisis dapat diketahui bahwa variabel bebas yang berpengaruh adalah variabel return on assets. Sedangkan variabel nonperforming loan dan financial distress tidak berpengaruh signifikan terhadap remunerasi direksi.

1. Nilai konstanta persamaan di atas adalah sebesar 9,828 yang dapat diartikan bahwa remunerasi direksi akan bernilai 9,828 jika variabel seperti non performing loan, financial distress dan return on assets tidak mengalami perubahan (peningkatan dan penurunan) atau konstan.

2. Pengujian hipotesis pertama menyatakan bahwa risiko bisnis tidak berpengaruh signifikan terhadap remunerasi direksi. Hasil uji $\mathrm{t}$ di peroleh bahwa koefisien regresi untuk variabel ROA sebesar 10,105 dengan nilai signifikansi (p-value) sebesar 0,054. Nilai signifikansi ini lebih besar dari tingkat signifikansi a 0,05, maka hipotesis pertama ditolak, berarti risiko kredit tidak berpengaruh signifikan terhadap remunerasi direksi.

3. Pengujian hipotesis kedua menyatakan bahwa financial distress berpengaruh negatif terhadap remunerasi direksi. Hasil uji t di peroleh bahwa koefisien regresi untuk variabel FDSTR sebesar 0,518 dengan nilai signifikansi (p- 
value) sebesar 0,170. Nilai signifikansi ini lebih besar dari tingkat signifikansi a 0,05, maka hipotesis kedua ditolak, berarti financial distress tidak berpengaruh signifikan terhadap remunerasi direksi.

1. Pengujian hipotesis ketiga menyatakan bahwa ROA berpengaruh positif terhadap remunerasi direksi. Hasil uji t di peroleh bahwa koefisien regresi untuk variabel ROA sebesar 45,084 dengan nilai signifikansi (p-value) sebesar 0,000. Nilai signifikansi ini lebih kecil dari tingkat signifikansi a 0,05, maka hipotesis ketiga diterima, berarti ROA berpengaruh positif signifikan terhadap remunerasi direksi.

Hasil uji statistik $\mathrm{t}$ yang ditampilkan tabel IV.10 menunjukan bahwa risiko kredit tidak berpengaruh signifikan terhadap remunerasi direksi. Risiko kredit memiliki nilai signifikansi yang lebih dari 0,05 yang mengakibatkan variabel ini tidak memiliki pengaruh signifikan terhadap remunerasi direksi. Berdasarkan hasil tersebut, maka hipotesis pertama penelitian ini ditolak. Hal ini tidak sejalan dengan penelitian yang dilakukan oleh (Heaney, 2005) yang menyatakan bahwa pihak principal akan mengeluarkan biaya berupa remunerasi kepada pengambil keputusan sebagai upah dalam pengambilan risiko. Serta juga tidak sesuai dengan penelitian (Fuad, 2015) yang menyatakan bahwa besaran remunerasi dapat dihitung menggunakan besaran risiko bisnis. Pemberian remunerasi yang lebih besar akan diberikan kepada perusahaan yang sehat sebagai reward dikarenakan telah memajukan bisnis perusahaan hal ini sesuai dengan penelitian yang dilakukan oleh (Ruparelia, 2016) pengujian hipotesis pertama membuktikan bahwa risiko kredit tidak berpengaruh signifikan terhadap remunerasi direksi. Hal ini dapat berarti bahwa ketidakpastian yang dialami oleh perusahaan dalam menghadapi kondisi bisnisnya untuk membiayai biaya operasionalnya membuat tidak berdampak terhadap pemberian remunerasi yang tinggi kepada pihak direksi. Ketika perusahaan sedang mengalami risiko kredit yang tinggi, maka akan cenderung untuk menyimpan dana yang tersedia untuk spekulasi jika terjadi adanya kerugian. Bank Pundi Indonesia Tbk. (BEKS) merupakan salah satu contoh 
perusahaan sektor perbankan yang mengalami penurunan rasio nonperforming loan pada tahun 2011-2016 dari sebesar 9.12\% menjadi 5.71\%, akan tetapi hal ini tidak berbanding lurus dengan pemberian remunerasi yang terus meningkat pada tahun 2011-2016 dari Rp 5.480 juta menjadi Rp 13.539 juta. Contoh lainnya pada PT Bank Indonesia Agroniaga Tbk. (AGRO) yang mengalami penurunan rasio non-performing loan pada tahun 2011-2016 dari sebesar $3.55 \%$ menjadi $2.88 \%$ yang, tetapi mengalmi peningkatan pada remunerasi yang diberikan dari 4.663 juta menjadi 12.783 juta.

Hasil uji statistik $\mathrm{t}$ yang ditampilkan tabel IV.10 menunjukan bahwa financial distress tidak signifikan terhadap remunerasi direksi. Financial distress memiliki nilai signifikansi yang lebih dari 0,05 yang mengakibatkan variabel ini tidak memiliki pengaruh signifikan terhadap remunerasi direksi. Berdasarkan hasil tersebut, maka hipotesis kedua penelitian ini ditolak. Hasil penelitian ini tidak sejalan dengan penelitian yang dilakukan oleh (Abdullah, 2006) yang menyatakan bahwa perusahaan dalam keadaan financial distress akan membayar total remunerasi lebih rendah dibandingkan perusahaan dalam keadaan sehat. Serta juga tidak sejalan denganhasil penelitian yang dilakukan (Probohudono et al., 2016) bahwa financial distress berpengaruh negatif terhadap remunerasi direksi. Pengujian hipotesis kedua membuktikan bahwa financial distress tidak berpengaruh signifikan terhadap remunerasi direksi. Hal ini dapat berarti bahwa kondisi keuangan perusahaan-perusahaan sektor perbankan tidak dalam kesulitan keuangan pada saat penelitian ini dilakukan sehingga berimbas pada tidak signifikannya pengaruh financial distress terhadap remunerasi direksi. Pemberian remunerasi pada perusahaan yang mengalami keadaan keuangan tidak baik, atau dikatakan distress, akan berbeda dengan perusahaan dengan kondisi keuangan yang baik atau non-distress. Ketika perusahaan dalam keadaan financial distress, kondisi keuangan dalam perusahaan sedang mengalami penurunan serta perusahaan akan mengalami kesulitan dalam melakukan pembayaran utang. Sebaliknya, ketika keadaan perusahaan dalam kondisi non-fnancial distress, maka kondisi keuangan yang 
ada dalam perusahaan sedang dalam keadaan normal bahkan meningkat dari biasanya. Hal tersebut akan berdampak pula pada besarnya pemberian remunerasi direksi. Remunerasi dalam keadaan perusahaan yang baik akan lebih tinggi daripada dalam perusahaan yang mengalami distress. PT Bank MNC International (BABP) Tbk. merupakan salah satu contoh mengalami financial distress pada tahun 2013 dan 2014, akan tetapi remunerasi direksi pada tahun itu mengalami peningkatan dari sebesar Rp.7.967 juta menjadi Rp.10.793 juta. Selain PT Bank JTrust (BCIC) Tbk. juga sempat mengalami financial distress pada tahun 2014 dan 2015, akan tetapi remunerasi direksi pada tahun itu mengalami peningkatan dari sebesar Rp.8.414 juta menjadi Rp.13.671 juta. Kondisi financial distress pada setiap Bank berbeda, sebagian besar bank yang di teliti dalam penelitian ini tidak mengalami financial distress, kalaupun ada financial distress hanya bersifat sementara, sehingga tidak memberikan efek yang signifikan pada remunerasi direksi. Perusahaan yang sedang mengalami masalah dalam likuiditas maka akan sangat memungkinkan perusahaan akan mulai memasuki masa kesulitan keuangan (financial distress), dan jika kondisi tersebut segera diatasi maka akan berakibat pada kebangkrutan usaha. Untuk menghindari kebangkrutan ini dibutuhkan berbagai kebijakan, strategi dan bantuan, baik dari pihak internal dan ekternal (Fahmi, 2013). Hampir sebagaian besar perusahaan yang diteliti yang perusahaan perbankan tidak mengalami kondisi financial distress. Sehingga hal tersebut menyebabkan kondisi financial distress tidak berpengaruh terhadap renumerasi direksi. Adapun perusahaan yang mengalami financial distress hanya pada tahun tertentu saja seperti BABP 2011, BEKS 2016, BNLI 2016, BSWD 2016. Financial distress yang tidak mempunyai dampak yang sistemik, ataupun financial distress yang lebih dari 3 tahun berturut-turut. Sehingga dapat disimpulkan bahwa keseluruhan perusahaan perbankan tidak mengalami financial distress.

Hasil uji statistik $\mathrm{t}$ yang ditampilkan tabel IV.10 menunjukan bahwa ROA signifikan terhadap remunerasi direksi. ROA memiliki nilai signifikansi 
yang kurang dari 0,05 yang mengakibatkan variabel ini memiliki pengaruh terhadap Remunerasi Direksi. Berdasarkan hasil tersebut, maka hipotesis ketiga penelitian ini diterima. Uji hipotesis ketiga membuktikan bahwa ROA berpengaruh positif dan signifikan terhadap remunerasi direksi. Hal ini dapat berarti bahwa kinerja perusahaan yang merupakan suatu akibat dari prestasi manajemen, dalam hal ini manajemen dapat mencapai tujuan perusahaan yaitu menghasilkan keuntungan dan meningkatkan nilai perusahaan, mempunyai timbal balik kepada mereka yaitu berupa peningkatan insentif remunerasi direksi, yang bisa berupa bonus, restricted share, opsi saham, dana pensiun, dan manfaat lainnya pada direksi. Pencapaian suatu kinerja yang baik tentunya akan berdampak pada perolehan laba dan peningkatan aset. Pihak direksi memerlukan suatu timbal balas jasa atas pencapaian baik kinerjanya dalam bentuk remunerasi. Kondisi demikian membuat perusahaan bersedia untuk memberikan remunerasi yang tinggi dengan tujuan memotivasi direksi agar bekerja lebih giat dan memajukan perusahaan. Oleh karena itu, pada saat kinerja perusahaan baik, maka tingkat remunerasi direksi yang akan dibagikan oleh perusahaan akan tinggi. PT Bank Rakyat Indonesia (BBRI) Tbk. merupakan salah satu contoh yang secara rata-rata mempunyai kinerja perusahaan (ROA) setiap tahunnya berkisar di nilai 4,65\%, akan tetapi jika dilihat dari nilai remunerasi direksi mengalami peningkatan hampir 29\% setiap tahunnya secara rata-rata. Yang dapat diketahui bahwa per tahun 2011, PT Bank Rakyat Indonesia (BBRI) Tbk. memberikan remunerasi direksi sebesar Rp.108.496 juta, dengan peningkatan rata-rata 29\% maka per tahun 2016, PT Bank Rakyat Indonesia (BBRI) Tbk. mampu memberikan remunerasi direksi sebesar Rp.366.787 juta. Hasil penelitian ini sejalan dengan penelitian yang dilakukan oleh (Agol et al., 2005) mengenai pengaruh ROA terhadap remunerasi membuktikan secara empiris bahwa ROA berpengaruh positif signifikan terhadap gaji dan bonus direksi. Hal ini sejalan dengan penelitian yang dilakukan oleh (Ruparelia, 2016) dan (Aggarwal \& Ghosh, 2015) yaitu peningkatan kinerja yang baik akan berpengaruh terhadap besaran remunerasi 
yang akan diterima oleh direksi serta penelitian oleh (Pangestu et al., 2019) mengatakan bahwa ada hubungan positif antara remunerasi direksi terhadap ROA dimana semakin tinggi pemberian remunerasi kepada direksi perusahaan akan membuat ROA dari perusahaan yang bersangkutan meningkat.

Berbeda dengan penelitian yang dilakukan oleh (Septianingsih \& Muslih, 2019) dan (Padia \& Callaghan, 2020) yang menyatakan bahwa remunerasi direksi tidak berpengaruh signifikan terhadap kinerja perusahaan. (Yunizar \& Rahardjo, 2014) yang menyatakan bahwa pertemuan komite audit atau remunerasi tidak memiliki pengaruh yang signifikan terhadap kinerja perusahaan (ROA).

Hal-hal terkait kinerja perusahaan yang diharapakan akan semakin baik kedepannya dilakukan dengan pemberian remunerasi. Pemberian remunerasi yang tinggi kepada para agent dipengaruhi oleh kinerja dan performa perusahaan yang baik.

\section{KESIMPULAN}

Berdasarkan hasil uji hipotesis dan analisis yang dilakukan pada penelitian ini, dapat diambil kesimpulan sebagai berikut: Non-Performing Loan Tidak Berpengaruh Signifikan Terhadap Remunerasi Direksi. Financial Distress Tidak Berpengaruh Signifikan Terhadap Remunerasi Direksi. ROA Berpengaruh Signifikan Terhadap Remunerasi Direksi.

\section{IMPLIKASI PENELITIAN}

Implikasi dari penelitian ini adalah kebijakan pemberian remunerasi oleh perusahaan dipengaruhi oleh kinerja perusahaan, sedangkan resiko bisni dan financial distress tidak dapat memberikan informasi tentang seberapa besar pengaruh terhadap remunerasi direksi, hal ini tentu berkaitan bagaimana kondisi kinerja perusahaan saat itu serta risiko kredit khususnya pada perusahaan perbankan pada saat itu. 


\section{REFERENSI}

Abdullah, F. (2006). Measuring service quality in higher education: HEdPERF versus SERVPERF. Marketing Intelligence \& Planning.

Aggarwal, R., \& Ghosh, A. (2015). Director's remuneration and correlation on firm's performance: A study from the Indian corporate. International Journal of Law and Management.

Agol, E., Steffen, J., Sari, R., \& Clarkson, W. (2005). On detecting terrestrial planets with timing of giant planet transits. Monthly Notices of the Royal Astronomical Society, 359(2), 567-579.

Agustia, I. M., Susyanti, J., \& Salim, M. A. (2019). Analisis Komparasi Potensi Kebangkrutan Dengan Menggunakan Metode Altman Z-Score (1968), Springate (1978) Dan Zmijewski (1984) Pada Industri Perbankan Yang Terdaftar Di Bursa Efek Indonesia (BEI) Periode Tahun 2016-2017. Jurnal Ilmiah Riset Manajemen, 8(1).

Atmaja, F. W. (2018). Pengaruh Risiko Bisnis, Financial Distress, Dan Kinerja Perusahaan Terhadap Remunerasi Direksi Pada Perusahaan Sektor Perbankan Yang Terdaftar Pada Bursa Efek Indonesia Tahun 2011-2016. Universitas Negeri Jakarta.

Azzahro, N. R., \& Soemaryono, S. (2020). Analisis Perbandingan Prediksi Kebangkrutan Pada Perusahaan Pertambangan Yang Terdaftar Di Bursa Efek Indonesia. Liability, 2(2), 53-72.

Bebchuk, L. A., \& Fried, J. M. (2006). Pay without performance: Overview of the issues. Academy of Management Perspectives, 20(1), 5-24.

Darsono, A. (2005). Pedoman Praktis Memahami Laporan Keuangan. Yogyakarta: CV Andi Offset.

Ferry, N. I. (2008). Manajemen Risiko Perbankan. Pemahaman Pendekatan, 3. 
Fitriana, H. (2010). Analisis kinerja keuangan perusahaan semen sebelum dan sesudah go public di Bursa Efek Jakarta oleh Heni Fitriana. Analisis Kinerja Keuangan Perusahaan Semen Sebelum Dan Sesudah Go Public Di Bursa Efek Jakarta Oleh Heni Fitriana.

Fahmi, i. (2013). Analisis Laporan Keuangan, Cetakan ke-3. Bandung: Alfabeta.

Fuad, D. A. (2015). Pengaruh Struktur Kepemilikan, Kinerja, dan Risiko Terhadap Kompensasi Eksekutif. Diponogoro Journal of Accounting Fakultas Akuntansi dan Bisnis, vol 4, no.2.

Godfrey, J., Hodgson, A., Tarca, A., Hamilton, J., \& Holmen, S. (2010). Accounting. John Wiley \& Sons, Inc.

Heaney, R. P. (2005). The vitamin D requirement in health and disease. he Journal of steroid biochemistry and molecular biology 97.1-2, 13-19.

Helgawati, M. (2017). Pengaruh Penerapan Tata Kelola Perusahaan, Ukuran Perusahaan Dan Leverage Terhadap Kesulitan Keuangan (Financial Distress)(Studi Pada Perusahaan Peserta CGPI Yang Terdaftar di BEI periode 2011-2014). Fakultas Ekonomi dan Bisnis Unpas Bandung.

Hery, S. E. (2016). Design The Business Plan for Start Up Entrepreneur: Mendesain Model Bisnis yang Kompetitif dan Menyusun Rencana Strategis yang Solid. Gramedia Widiasarana Indonesia.

Hidayat, T. (2019). Manajemen Risiko Pembiayaan Lakusemar Pada Bprs Bina Amanah Satria Purwokerto. IAIN Purwokerto.

Karim, A. A., \& Islam, B. (2006). Analisis Fiqih dan Keuangan, Jakarta, PT. RajaGrafindo Persada.

Kusumaningrum, D. (2022). Analisis Tingkat Kesehatan Bank Dan Potensi Financial Distress Menggunakan Metode Rgec Pada Bank Aceh Syariah Tahun 2016-2020. Moneter: Jurnal Keuangan dan Perbankan 10.1, 10-15. 
Lokman, N. a. (2020). How Are Company Size, Financial Performance and Corporate Governance Related to Directors' Remuneration? Research in World Economy 11.6.

Mukherjee, S., \& Mahakud, J. (2012). Are trade-off and pecking order theories of capital structure mutually exclusive? Journal of Management Research (09725814), 12(1).

Neokleous, C. I. (2015). Executive Compensationas a Corporate Governance Problem. University of Essex Student Research Online. vol.7.

Nora. (2016). Pengaruh Financial Indicators, Ukuran Perusahaan dan Kepemilikan Institusional Terhadap Financial Distress (Studi Empiris pada Perusahaan Property dan Real Estate yang Terdaftar Di BEI). (Doctoral dissertation, Stie Perbanas Surabaya).

Padia, N., \& Callaghan, C. W. (2020). Executive director remuneration and company performance: panel evidence from South Africa for the years following King III. Personnel Review.

Pangestu, A. P., Agustia, S., \& Rachman, R. A. (2019). Pengaruh Pemberian Remunerasi Direksi Terhadap Kinerja Keuangan Perusahaan Publik di Indonesia. Studi Akuntansi Dan Keuangan Indonesia, 2(1), 49-77.

Platt, H. D., \& Platt, M. B. (2002). Predicting corporate financial distress: Reflections on choice-based sample bias. Journal of Economics and Finance, 26(2), 184-199.

Probohudono, A. N., Perwitasari, D., \& Putra, R. P. (2016). Faktor-Faktor Yang Memengaruhi Remunerasi Direksi: Studi Komparasi Perusahaan Di Australia, Singapura, Indonesia, Dan Malaysia. Jurnal Akuntansi Dan Keuangan Indonesia, 13(1), 3. 
Robert N Anthony, V. G. (2007). Management Control Systems 12th. New York: McGraw-Hill.

Ruparelia, A. N. (2016). Relationship between Board Remuneration and Financial Performance in the Kenyan Financial Services Industry. International Journal of Financial Research, vol.7 no.2.

Septianingsih, L. R., \& Muslih, M. (2019). Board size, ownership diffusion, gender diversity, media exposure, dan Pengungkapan corporate social responsibility (studi kasus pada perusahaan indeks SRI-KEHATI yang terdaftar di Bursa Efek Indonesia Periode 2013-2017). Jurnal Akuntansi, 11(2), 218-229.

Sucipto, A. C. (2017). Pengaruh Corporate Social Responsibility Terhadap Kinerja Keuangan Perusahaan (Studi Pada Perusahaan Manufaktur Yang Terdaftar Di Bei Tahun 2013-2015). Universitas Muria Kudus.

Sugiyono. (2018). Metode Penelitian Kuantitatif. Yogyakarta: Alfabeta.

Umam, K., \& Sutanto, H. (2013). Pasar Modal Syariah. Bandung. Pustaka Setia.

Wells, P. J. (2015). Executive Remuneration: Regulatory Reforms in UK Company Law. International Journal of Law and Management, vol.57, no.4.

Wibowo, E. (2010). Implementasi good corporate governance di Indonesia. Jurnal Ekonomi Dan Kewirausahaan, 10(2).

Yunizar, R. I., \& Rahardjo, S. N. (2014). Pengaruh Mekanisme Corporate Governance dan Ukuran Perusahaan terhadap Kinerja Keuangan Perusahaan. Diponegoro Journal of Accounting, 175-184.

Yusuf, M. a. (2019). Analisis Efektifitas Penggunaan Cadangan Devisa, Utang Luar Negeri dan Ekspor Terhadap Stabilitas Nilai Tukar. Jurnal Penelitian Pendidikan Sosial Humaniora 4.2, 544-561. 
www.Detk.com. (2017).

www.idx.co.id. (2020).

www.kompas.com. (2017) 